\title{
Cell-Wide Survey of Amide-Bonded Lysine Modifications by Using Deacetylase CobB
}

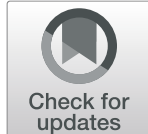

Yun Wei ${ }^{1,2}$, Wan-Jie Yang ${ }^{1,2}$, Qi-Jun Wang ${ }^{3}$, Peng-Cheng Linn ${ }^{4}$, Jian-Yuan Zhao ${ }^{1,2}$, Wei Xu ${ }^{1,2}$, Shi-Min Zhao ${ }^{1,2,4^{*}}$ and Xia-Di He ${ }^{1,2^{*}}$

\begin{abstract}
Background: Lysine post-translational modifications are important regulators of protein function. Proteomic and biochemical approaches have resulted in identification of several lysine modifications, including acetylation, crotonylation, and succinylation. Here, we developed an approach for surveying amide-bonded lysine modifications in the proteome of human tissues/cells based on the observation that many lysine modifications are amide-bonded and that the Salmonella enterica deacetylase, CobB, is an amidase.
\end{abstract}

Results: After the proteome of human tissues/cells was denatured and the non-covalently bonded metabolites were removed by acetone washes, and the amide-bonded modifiers were released by CobB and analyzed using liquid- and/or gas chromatography/mass spectrometry metabolomic analysis. This protocol, which required 3-4 days for completion, was used to qualitatively identify more than 40 documented and unreported lysine modifications from the human proteome and to quantitatively analyze dynamic changes in targeted amide-bonded lysine modifications.

Conclusions: We developed a method that was capable of monitoring and quantifying amide-bonded lysine modifications in cells of different origins.

Keywords: Lysine post-translational modification, CobB deacetylase, Proteome

\section{Background}

Many amino acids are modified post translationally to regulate functions of proteins. Adding phosphor groups to serine, threonine and tyrosine constitutes protein phosphorylation and one of the major mechanisms of cellular signal transduction $[1,2]$. Other amino acid residues such as histidine, proline and cysteine can also be phosphorylated [3, 4], hydroxylated [5] or acylated [6], respectively, to convey various biological functions. Lysine is the most heavily modified residue in proteins. More than 90 different lysine modifications have been identified on lysine [7]. Many lysine modifications are physiologically significant and have been studied extensively. For example, lysine acetylation of histones and other nuclear proteins is critical for chromatin remodeling and regulation of gene tran-

\footnotetext{
*Correspondence: shiminzhao1966@163.com; 12110700006@fudan.edu.cn 1 Institutes of Biomedical Sciences, Obstetrics \& Gynecology Hospital of Fudan University, State Key Lab of Genetic Engineering and School of Life Sciences, Shanghai, People's Republic of China

Full list of author information is available at the end of the article
}

scription $[8,9]$, whereas acetylation of metabolism-related enzymes is important for regulation of metabolism [10, 11]. Lysine methylation marks histones and other proteins for regulation of transcription and protein activity [12]. Although lysine methylation is an important modification, the majority of lysine modifications are amide-bonded. This was recently confirmed after an array of metabolites, including propionate, butyrate, malonate, crotonate, and succinate and their respective coenzyme A derivatives, was shown to contain amide-bonded lysine residues [13-16].

Cell-wide survey of known lysine modifications, such as acetylation [17] or methylation [18], has been documented. However, a more comprehensive understanding of the importance of lysine modifications will require elucidation of the cell-wide dynamics and types of lysine modifications. Thus, protocols for systematically and quantitatively surveying different types of lysine modifications are necessary. Because most lysine modifications are formed via amide bonds, cell-wide surveys of lysine modifications can be conducted once a nonspecific amidase is identified. 
Accordingly, in this study, we developed an approach for surveying amide-bonded lysine modifications in the proteome of human tissues/cells.

\section{Results}

While investigating the activities of Salmonella enterica deacetylase CobB [10], we unexpectedly observed that CobB possesses nonspecific amidase activity. Recombinant CobB purified from Escherichia coli efficiently cleaved all tested amide-bonded lysine modifications, including propionylation, succinylation, crotonylation, and acetylation, on synthetic peptides (Fig. 1). This suggested that CobB could be used as a general amidase to release amide-bonded lysine modifiers and thereby identify novel lysine modifications in cells. Thus, we developed a CobB-based protocol to survey amide-bonded lysine modifications in human cells. Briefly, proteins in cell lysates were precipitated and washed extensively with acetone to remove any small molecules that were noncovalently bound to the proteins, the amide-bonded modifications to the proteome were released by CobB treatment, and the released modifiers were analyzed by liquid chromatography/mass spectrometry (LC/MS) or gas chromatography/mass spectrometry (GC/MS).
Metabolites, the levels of which were significantly higher in CobB-treated samples than in untreated control samples, were considered possible lysine modifiers (Fig. 2) because only the $\varepsilon$-amine of lysine and the $\mathrm{N}$-terminus amine of a protein could form amide bonds; however, we confirmed that the amide bonds formed with the $\mathrm{N}$ terminal amine were not cleaved by CobB. Using this protocol, we successfully identified more than 40 new lysine modifications, including lysine aminoacylations, which facilitate sensing and signal transduction of intracellular amino acids in human liver cancer tissues and HEK293T cells [19].

A successful survey using the above described protocol will generate the following results: 1 ) significantly higher (> 2 -fold, $p$ value $<0.05)$ GC or LC peak areas should be obtained in CobB-treated samples than in matched untreated samples (Fig. 3-1); 2) the MS/MS fingerprint spectra (Fig. 3-2) should match some of the spectra in the NIST mass spectral library (Fig. 3-3); 3) the retention time in GC or LC and the MS/MS spectrum of identified metabolites should match those of authentic standard metabolites (Fig. 3-4). Insignificant increases ( $<2$ fold, $p$ value $<0.05$ ) in GC or LC peak areas are often related to insufficient removal of non-covalently bonded metabolites or CobB

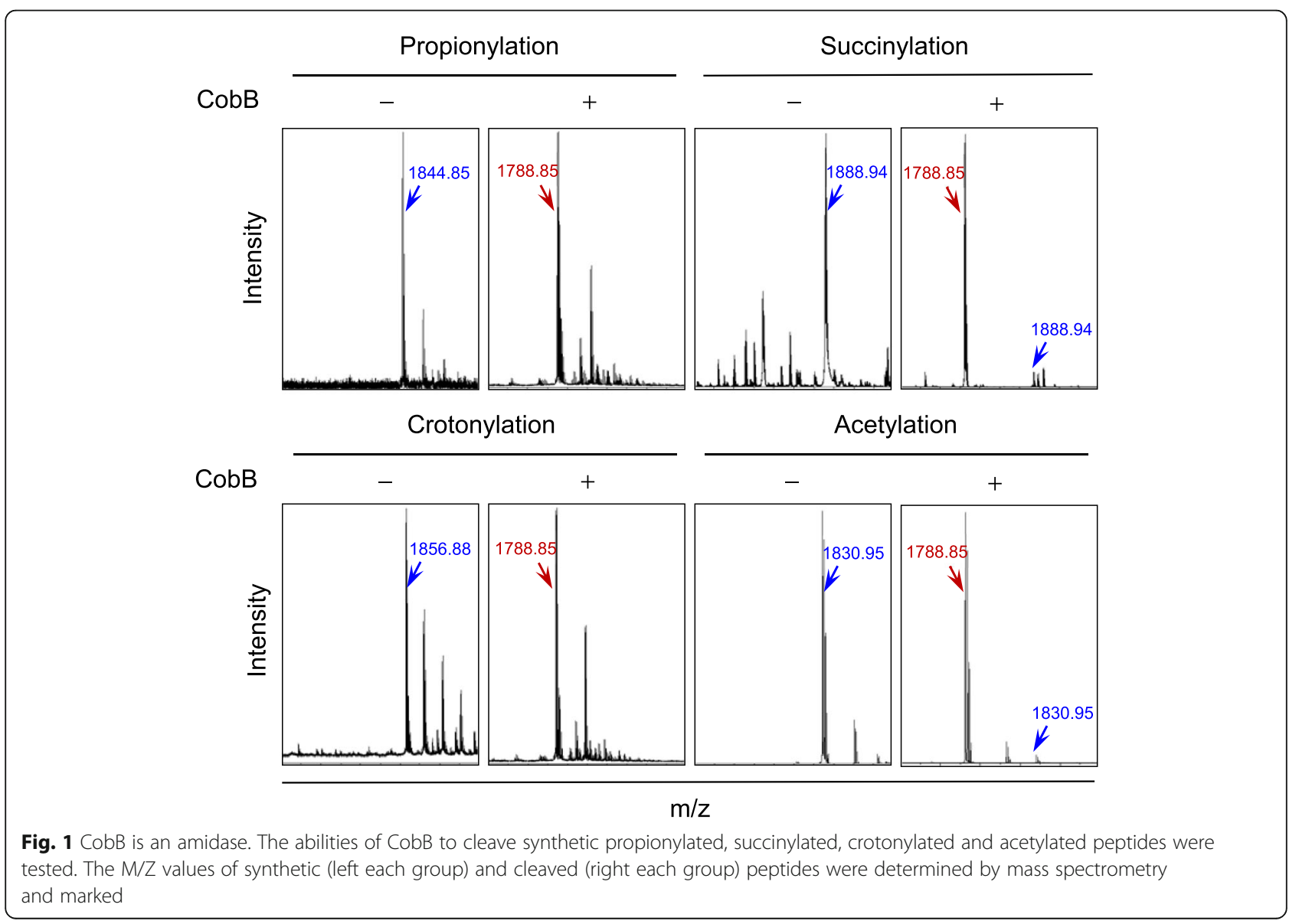




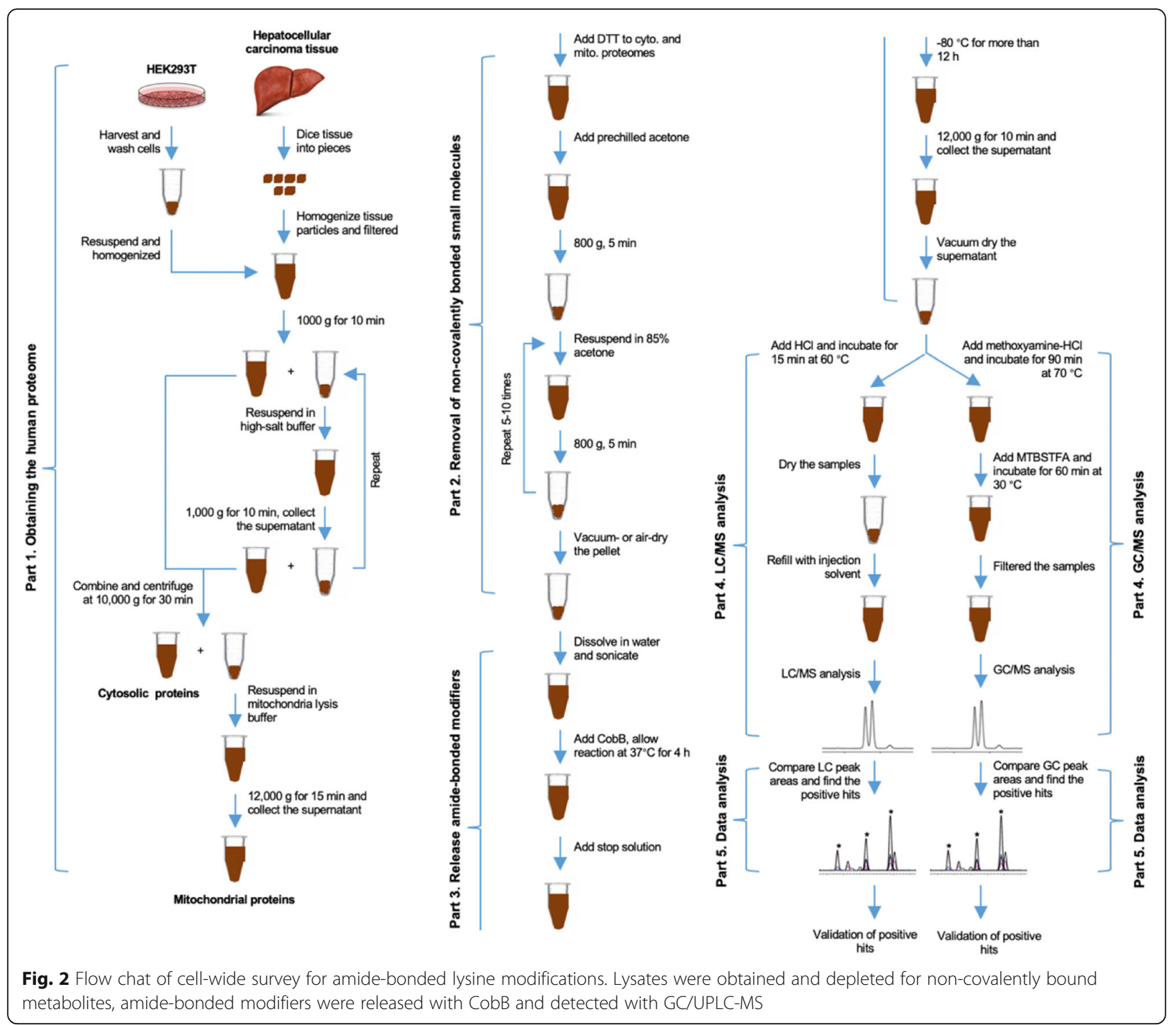

inactivation; a lack of GC or LC peaks with significant increases in area may be related to the first reason, whereas a lack of significant increases in GC or LC peak areas may be related to the second reason. The protocol can be improved accordingly.

\section{Discussion}

With the increasing discovery of the importance of PTMs, there is a growing need for discovery of novel PTMs. This protocol represents a general method for identifying and quantitatively analyzing amide-bonded modifications in cells. By using this method, it is not difficult to find dozens of new PTMs. Although we successfully used the method to identify amide-bonded lysine modifications in human kidney and liver cancer cells [19], this approach could also be applied to cell types of other human tissues or origins, as long as the proteome of these cells (bacteria, plants, and other mammalian cells) is readily available. Moreover, a welldesigned and well-performed analysis will allow quantification of the dynamic changes in cellular amide-bonded lysine modifications. Of note, the principle of our survey can be expanded to detect other PTMs of distinct chemical natures. For example, if a proper cleaving enzyme is identified, modifications such as acylation in cysteine, ubiquitinoylation or SUMOylation in glycine and glycosylation on various amino acids can be screened cell wide.

Lysine modifications are identified using distinct approaches (Table 1). For example, investigations on biochemical reactions have led to the identification of lysine acetylation [20] and methylation [21], and proteomic analysis has resulted in the identification of a 
1
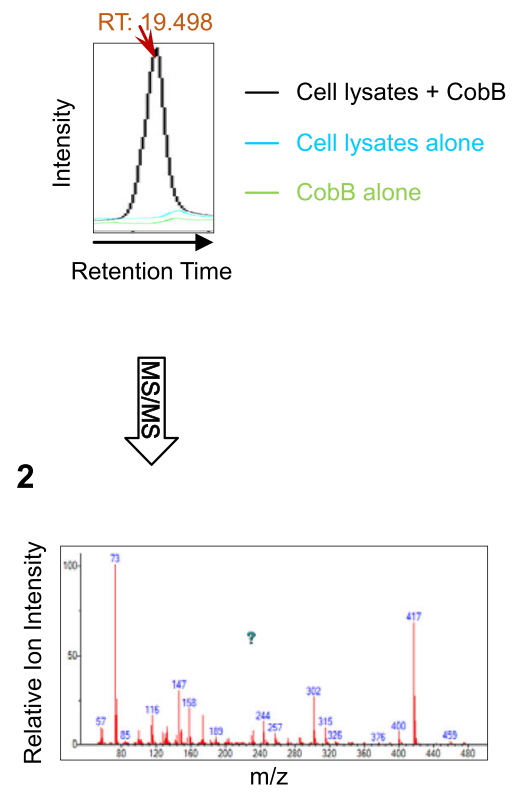

2

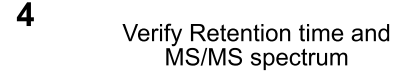

3
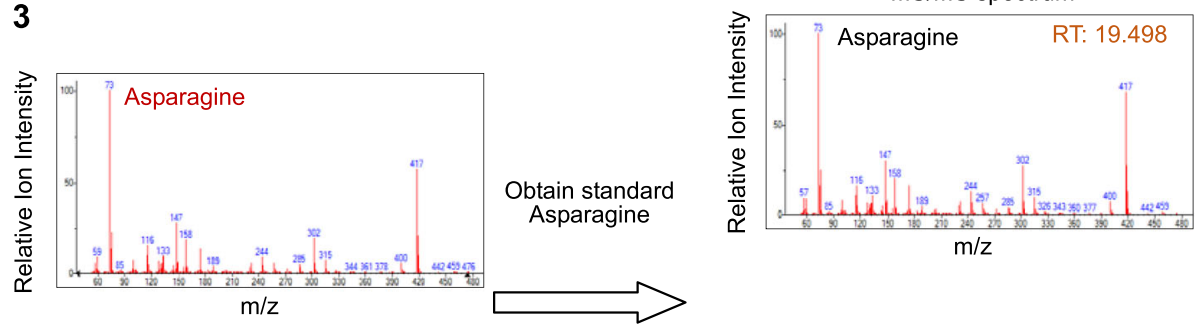

Fig. 3 An example flow chat of how a positive identification (asparagine) was obtained. A GC peak at certain retention time (19.498 min) is generated by CobB treatment (1), the MS/MS spectrum of the 19.498 min peak generated by CobB treatment (2), Searching against NIST library identified that the metabolite of 19.498 min peak was asparagine (3), the standard asparagine generate the same GC retention time and MS/MS spectrum as the metabolite generated by CobB treatment (4)

Table 1 Comparison with other methods

\begin{tabular}{lll}
\hline & Advantage & Disadvantage \\
\hline Our method & 1. Multiple modifications identification & 1. Only amide-bond lysine modifications \\
& 2. Known the demodification enzyme & $\begin{array}{l}\text { 2. Higher false positive ratio } \\
\text { 3. More expertise needed }\end{array}$ \\
$\begin{array}{l}\text { Biochemical } \\
\text { Journal, } 1963\end{array}$ & 1. Lower false positive ratio & 1. Only amide-bond lysine modifications \\
2. Less expertise needed & & 2. One modification identification \\
Molecular \& Cellular & 1. Lower false positive ratio & 3. Unkown the demodification enzyme \\
& 2. Less expertise needed & 1. Only amide-bond lysinemodifications \\
& & 2. One modification identification \\
& & 3. Unkown the demodification enzyme \\
\hline
\end{tabular}


number of lysine modifications, including propionylation [13], butyrylation [13], and crotonylation [16]. Our current protocol utilized the amidase activity of CobB in combination with metabolomic analysis to identify multiple lysine modifications. To the best of our knowledge, this is the first protocol to allow cell-wide identification and quantification of amide-bonded lysine modifications.

We confirmed that CobB did not cleave the N-terminus amine-derived amide bonds and peptide bonds in the protein backbone, suggesting that modifiers obtained after CobB cleavage were putative lysine modifiers [19]. However, the protocol had two limitations. First, there was a slight possibility that the CobB-cleaved modifiers were not lysine modifiers because we did not test whether CobB could cleave other chemical bonds. Second, although we identified an array of new lysine modifications using this protocol [19], whether this approach may enable complete identification of amide-bonded lysine modifications was unclear because the ability of CobB to cleave all types of amide-bonded modifications could not be exhaustively tested. Nevertheless, our protocol represents a useful tool for surveying potential novel lysine modifications.

\section{Conclusions}

This method was developed because of the lack of method for systematically and quantitatively surveying different types of lysine modifications. We propose a method that can be accurate, facile, and reproducible to identify and quantify new amide-bonded lysine modifications in cells of different origins.

\section{Methods}

\section{Reagents}

Methanol (Sigma, St. Louis, MO, USA; cat. no. 34860-1 L-R).

! CAUTION Methanol is highly flammable and toxic, handle with caution.

Pyridine (Sigma; cat. no. 270407-1 L).

Methoxamine hydrochloride (Sigma; cat. no. 226904).

$\mathrm{N}$-tert-Butyldimethylsilyl-N-methyltrifluoro-acetamide

(MTBSTFA; Sigma; cat. no. 394882).

Tris base (Sangon, cat. no. TB0194).

Tryptone (OXOID; cat. no. LP0042).

Yeast extracts (OXOID; cat. no. LP0021).

$\mathrm{NaCl}$ (Sangon; cat. no. SB0476).

Isopropyl $\beta$-D-1-thiogalactopyranoside (IPTG; Sangon; cat. no. A100487).

Dithiothreitol (DTT; Merck; cat. no. 233156).

Adonitol (Sigma; cat. no. A5502).

Ampicillin (Sangon; cat. no. A610028).

Urea (Sangon; cat. no. A510907).

Imidazole (Sangon; cat. no. A500529).

Mitochondrial lysis buffer (Pierce; cat. no. 89874).
Sodium dodecyl sulfate sodium salt (SDS; Sangon; cat. no. 0227).

Ammonium persulfate (Sigma; cat. no. A3678).

Acrylamide (Sangon; cat. no. 0341).

Bisacrylamide (Sangon; cat. no. 0172.

! CAUTION Acrylamide and bisacrylamide are potent neurotoxins. Use appropriate safety measures, such as protective gloves and safety goggles, and handle under adequate ventilation.

$\mathrm{N}$ ",N",N",N"-tetramethylenethylendiamide (BI; cat. no. TB0508).

$\beta$-Mercaptoethanol (AMRESCO; cat. no. 0482).

! CAUTION $\beta$-Mercaptoethanol fumes are toxic and should be dispersed under a fume hood.

Nicotinamide (Sigma; cat. no. N0636).

Aprotinin (BBI; cat. no. AD0153).

Leupeptin (Sangon; cat. no. LJ580).

Pepstain (Sangon; cat. no. J583).

$\mathrm{KCl}$ (BBI; cat. no. PB0440).

Nicotinamide adenine dinucleotide (Sigma; cat. no. N8285).

Mitochondrial lysis buffer (Pierce; cat. no. 89874).

HEPES (Sangon; cat. no. H0511).

Ethylenediaminetetraacetic acid (EDTA; Sangon; cat. no. 0105).

$\mathrm{MgCl}_{2}$ (Fluka; cat. no. 63063).

1-Butanol (Sigma; cat. no. B7906).

HyClone phosphate-buffered saline (PBS), 10× (GE Healthcare; cat. no. SH30258.01).

Acetone (Sigma; cat. no. 270725).

! CAUTION Acetone can damage the mucosa of the mouth and can irritate and damage skin. Acetone should be used with appropriate safety measures, such as protective gloves, glasses, and clothing as well as adequate ventilation. Acetone should be stored in an explosionor flame-proof freezer.

Coomassie brilliant blue G-250 (Serva; cat. no. 17524).

Protein Assay Dye Reagent Concentrate (for Bradford Assay; Bio-Rad, Hercules, CA, USA; cat. no. 500-0006).

! CAUTION This reagent is toxic; handle with care.

Hydrochloric acid ( $\mathrm{HCl}$; EMD Millipore; cat. no. HX0603-4).

! CAUTION $\mathrm{HCl}$ is highly corrosive and toxic; handle with care.

Alanine (Sigma; cat. no. 05129).

Aspartate (Sigma; cat. no. A9310-0).

Asparagine (Sigma; cat. no. A0884).

Arginine (Sigma; cat. no. A5006).

Cysteine (Sigma; cat. no. V900400).

Glycine (Sigma; cat. no. 4102250).

Glutamine (Sigma; cat. no. G3126). 
Glutamate (Sigma; cat. no. G8415).

Histidine (Sigma; cat. no. H6034).

Isoleucine (Sigma; cat. no. I2752).

Lysine (Sigma; cat. no. 62840).

Leucine (Sigma; cat. no. L8912).

Methionine (Sigma; cat. no. V900487).

Phenylalanine (Sigma; cat. no. V900615).

Proline (Sigma; cat. no. P0380).

Serine (Sigma; cat. no. S4311).

Tyrosine (Sigma; cat. no. T3754).

Threonine (Sigma; cat. no. T8625).

Tryptophan (Sigma; cat. no. V900470).

Valine (Sigma; cat. no. V0500).

! CAUTION All experiments should be performed in accordance with relevant guidelines and regulations. A physician or a nurse practitioner must obtain informed consent from donors.

\section{Equipment}

0.45- $\mu \mathrm{m}$ Filter-Top Bottle (Corning, Corning, NY, USA; Cat. No. 430625)

100- $\mu \mathrm{m}$-diameter cell filter (Thermo; cat. no. 08-771-19).

50-mL conical tubes (Thermo; cat. no. 339652).

15-mL conical tubes (Thermo; cat. no. 339650).

1.5-mL Tubes (Axygen; Cat. No. MCT-150-C)

Dounce homogenizer (Active Motif; cat. no. 40401).

Concentrator 5301 (Eppendorf; cat. no. 5301).

Centrifuge 5810R (Eppendorf; cat. no. 5810R).

Centrifuge 5424R (Eppendorf; cat. no. 5424R).

Vacuum drier (Eppendorf; cat. no. Concentrator plus). Gel electrophoresis apparatus (Bio-Rad; cat. no. 1658001).

Power supply ( $500 \mathrm{~V}, 500 \mathrm{~mA}$; SDS-polyacrylamide gel electrophoresis, PAGE; Bio-Rad; cat. no. 1645050).

Typhoon Trio imaging system (GE Healthcare; cat. no. FLA9500).

Fast protein liquid chromatography (FPLC) system with pumps, UV detector, fraction collector, and 2$\mathrm{mL}$ sample loop (GE Healthcare; cat. no. AKTAFPLC).

Nickel resin column (GE Healthcare; cat. no. 17-5217-01).

Desalination column (GE Healthcare; cat. no. 17-1408-01).

9-mm tread screw neck vial (ANPEL; cat. no. VAAP32009E-1232-100).

0.22- $\mu \mathrm{m}$ Syringe-Driven Filter Unit (Millex; Cat. No. SLGV004SL)

Low-temperature ultra-high pressure continuous flow cell disrupter (JNBIO; cat. no. JN-3000 PLUS).

Gas chromatograph (Agilent; 7890B gas chromatograph).

Mass spectrometer (Agilent; 5977B mass spectrometer).

$-80^{\circ} \mathrm{C}$ freezer (Thermo; cat. no. Forma 700).

Termovap Sample Concentrator (Organomation; cat. no. KL-11250-JG).

\section{Reagent Setup \\ Homogenization Buffer}

Homogenization buffer was composed of $10 \mathrm{mM} \mathrm{KCl}, 1.5$ $\mathrm{mM} \mathrm{MgCl}, 10 \mathrm{mM}$ Tris, and $5 \mathrm{mM}$ nicotinamide. The solution was prepared by dissolving $0.373 \mathrm{~g} \mathrm{KCl}, 0.071 \mathrm{~g} \mathrm{MgCl}_{2}$, $0.606 \mathrm{~g}$ Tris, and $0.305 \mathrm{~g}$ nicotinamide in $400 \mathrm{~mL}$ deionized water, adjusting the $\mathrm{pH}$ to 7.5 with $\mathrm{HCl}$, and adding deionized water to a final volume of $500 \mathrm{~mL}$. This solution can be stored for up to 1 month at room temperature before use.

\section{Oximation Mix (for GC/MS)}

This solution was composed of $250 \mathrm{mM}$ methoxyamine hydrochloride in pyridine. This solution was prepared by dissolving $20 \mathrm{mg}$ methoxyamine hydrochloride in $1 \mathrm{~mL}$ pyridine. This solution must be freshly prepared on the day of the experiment.

\section{Derivatization Mix (for GC/MS)}

This solution was composed of $20 \%$ (v/v) MTBSTFA in pyridine. This solution was prepared made by dissolving $200 \mu \mathrm{L}$ MTBSTFA in $800 \mu \mathrm{L}$ pyridine. This solution must be freshly prepared on the day of the experiment.

\section{Derivatization Mix (for LC/MS)}

This solution was composed of $3 \mathrm{M} \mathrm{HCl}$ in 1-butanol. This solution was prepared by dissolving $250 \mu \mathrm{L} \mathrm{HCl}$ in $750 \mu \mathrm{L}$ 1-butanol. This solution must be freshly prepared on the day of the experiment.

\section{High-Salt Buffer}

This solution was composed of $20 \mathrm{mM}$ Tris, $25 \%$ (v/v) glycerol, $1.5 \mathrm{mM} \mathrm{MgCl} 2,0.2 \mathrm{mM}$ EDTA, and $1.2 \mathrm{M} \mathrm{KCl}$. The solution was prepared by dissolving $1.211 \mathrm{~g}$ Tris, $12.5 \mathrm{~mL}$ glycerol, $0.071 \mathrm{~g} \mathrm{MgCl}_{2}, 0.029 \mathrm{~g}$ EDTA, and $44.730 \mathrm{~g} \mathrm{KCl}$ in $400 \mathrm{~mL}$ deionized water; adjusting the $\mathrm{pH}$ to 7.4 with $\mathrm{HCl}$; and adding deionized water to a final volume of $500 \mathrm{~mL}$. This solution can be stored for up to 1 month at room temperature before use. Add protease inhibitors described below to a $1 \times$ concentration just before use for cell lysis.

\section{Coomassie Brilliant Blue}

This solution was prepared with $0.25 \%(\mathrm{w} / \mathrm{v})$ Coomassie brilliant blue G-250, 45\% (v/v) methanol, and 10\% (v/v) acetic acid. G-250 brilliant blue powder was solubilized in methanol, acetic acid was added, and deionized water was added to an appropriate volume. The solution was filtered through a $0.45-\mu \mathrm{m}$ filter-top bottle before immediate use and could be stored at room temperature for future use. 


\section{Acrylamide:Bisacrylamide Solution (for Making SDS Gels)}

This solution consisted of $250 \mathrm{~g}$ acrylamide dissolved in $417 \mathrm{~mL}$ deionized water. The solution was prepared by stirring the acrylamide solution overnight before adding $1.67 \mathrm{~g}$ bisacrylamide. The solution was filtered through a $0.45-\mu \mathrm{m}$ filter-top bottle before use and could be stored at room temperature $\left(20-25^{\circ} \mathrm{C}\right)$ in a dark container.

\section{Electrophoresis Running Buffer}

The buffer was prepared by dissolving $3.02 \mathrm{~g}$ Tris base, $18.8 \mathrm{~g}$ glycine, and $1 \mathrm{~g}$ SDS in $1 \mathrm{~L}$ deionized water. This buffer could be stored at room temperature until use.

\section{PBS}

PBS was composed of $137 \mathrm{mM} \mathrm{NaCl}, 8 \mathrm{mM} \mathrm{Na} 2 \mathrm{HPO}_{4}$, $2.7 \mathrm{mM} \mathrm{KCl}$, and $1.47 \mathrm{mM} \mathrm{KH}_{2} \mathrm{PO}_{4}, \mathrm{pH} 7.1$, in deionized water. The solution was prepared by dissolving $8 \mathrm{~g} \mathrm{NaCl}$, $1.14 \mathrm{~g} \mathrm{Na}_{2} \mathrm{HPO}_{4}, 200 \mathrm{mg} \mathrm{KCl}$, and $200 \mathrm{mg} \mathrm{KH}_{2} \mathrm{PO}_{4}$ in $800 \mathrm{~mL}$ deionized water; adjusting the $\mathrm{pH}$ to 7.1 with $\mathrm{HCl}$; and bringing the volume up to $1 \mathrm{~L}$ with additional deionized water. The solution was autoclaved in a glass bottle to sterilize. This buffer can be stored at room temperature for at least several months.

\section{Binding Buffer (for CobB Purification)}

Binding buffer was composed of $100 \mathrm{mM}$ sodium phosphate, $150 \mathrm{mM} \mathrm{NaCl}$, and $20 \mathrm{mM}$ imidazole. The solution was prepared by dissolving $8.197 \mathrm{~g}$ sodium phosphate, $4.383 \mathrm{~g} \mathrm{NaCl}$, and $0.681 \mathrm{~g}$ imidazole in $400 \mathrm{~mL}$ deionized water; adjusting the $\mathrm{pH}$ to 7.2 with $\mathrm{HCl}$; and adding deionized water to a final volume of $500 \mathrm{~mL}$. This solution must be freshly prepared on the day of the experiment.

\section{Elution Buffer (for CobB Purification)}

Elution buffer was composed of $100 \mathrm{mM}$ sodium phosphate, $150 \mathrm{mM} \mathrm{NaCl}$, and $300 \mathrm{mM}$ imidazole. The solution was prepared by dissolving $8.197 \mathrm{~g}$ sodium phosphate, $4.383 \mathrm{~g} \mathrm{NaCl}$, and $10.212 \mathrm{~g}$ imidazole in $400 \mathrm{~mL}$ deionized water; adjusting the $\mathrm{pH}$ to 7.2 with $\mathrm{HCl}$; and adding deionized water to a final volume of $500 \mathrm{~mL}$. This solution must be freshly prepared on the day of the experiment.

\section{Desalination Buffer (for CobB Purification)}

Desalination buffer was composed of $50 \mathrm{mM}$ Tris and 150 $\mathrm{mM} \mathrm{NaCl}$. The solution was prepared by dissolving $3.029 \mathrm{~g}$ Tris base and $4.383 \mathrm{~g} \mathrm{NaCl}$ in $400 \mathrm{~mL}$ deionized water, adjusting the $\mathrm{pH}$ to 7.5 with $\mathrm{HCl}$, and adding deionized water to a final volume of $500 \mathrm{~mL}$. This solution can be stored for up to 1 month at room temperature before use.

\section{Protease Inhibitor Cocktail (50x)}

This solution contained $50 \mathrm{mM}$ PMSF, $0.05 \mathrm{mg} / \mathrm{mL}$ aprotinnin, $0.05 \mathrm{mg} / \mathrm{mL}$ leupeptin, and $0.05 \mathrm{mg} / \mathrm{mL}$ pepstatin in dimethyl sulfoxide. This solution can be stored for up to 12 weeks at $-20^{\circ} \mathrm{C}$ and diluted 50 -fold $(\mathrm{v} / \mathrm{v})$ before use.

$\triangle$ CRITICAL $1 \mathrm{mM}$ DTT and PMSF should be added to the diluted protease inhibitor cocktail solution before use.

! CAUTION Protease Inhibitor Cocktail is extremely toxic; handle with care.

\section{Stop Solution (for CobB Cleavage)}

Prechilled $\left(-80^{\circ} \mathrm{C}\right)$ methanol.

\section{Experimental Design}

In addition to the cleavage of amide-bonded lysine modifiers by CobB, the key to the success of this protocol was related to obtaining precleaned proteomes. To achieve this goal, the proteomes of human cells were denatured using 85\% acetone, which allowed further removal of non-covalently bonded metabolites while preserving covalently bonded lysine modifications and inactivated enzymes that may remove the modification. The denatured proteome was subject to extensive washing with $85 \%$ acetone to remove non-covalently bonded metabolites. The "precleaned" proteome was then subjected to CobB treatment to release the amidebonded lysine modifiers, and the cleaved modifiers were obtained by collecting the supernatants from the centrifuged denatured CobB reaction mixture. The cleaved modifiers in the supernatant were directly assayed using LC/MS, GC/MS, or both after the modifiers were oximated by methoxyamine hydrochloride. Notably, CobB-untreated samples should be run in parallel with CobB-treated samples as controls.

Table 2 Quantification of targeted lysine modifications TIMING: 3-4 days for each run

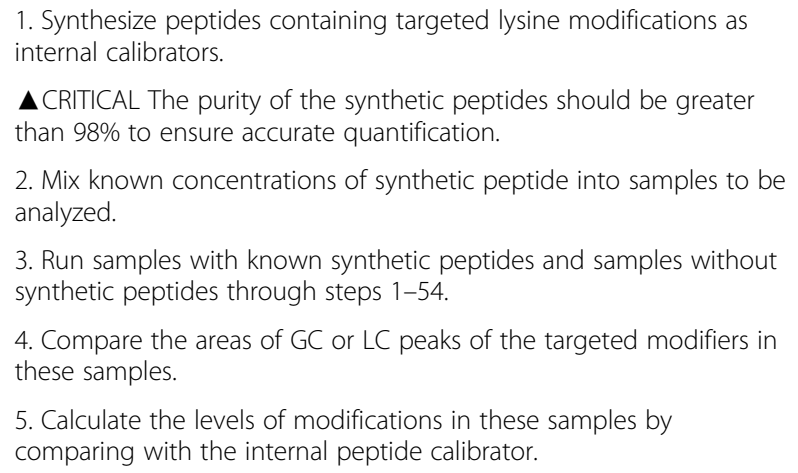

$\boldsymbol{\Delta}$ CRITICAL The purity of the synthetic peptides should be greater than $98 \%$ to ensure accurate quantification.

2. Mix known concentrations of synthetic peptide into samples to be analyzed.

3. Run samples with known synthetic peptides and samples without synthetic peptides through steps 1-54.

4. Compare the areas of GC or LC peaks of the targeted modifiers in these samples.

5. Calculate the levels of modifications in these samples by comparing with the internal peptide calibrator.

6. Alternatively, obtain a working curve by running various levels of synthetic peptides through steps 1-54, and compare areas of GC or $\mathrm{LC}$ peaks of samples with the working curve. 


\section{Procedure}

This protocol can be used to survey lysine modifications (steps 1-59, Fig. 2) or to quantify targeted lysine modifications (Table 2).

\section{Obtaining the Human Proteome •TIMING: 1-5 H}

1. The human proteome was obtained from either hepatocellular carcinoma (HCC) tissue or HEK293T cultured human embryonic kidney cells. HCC tissues were obtained with consent from the patient and processed (start from step 2) within $2 \mathrm{~h}$ of the patient's operation. HEK293T cells were processed (start from step 13) within 15 min of harvesting.

$\triangle$ CRITICAL The following steps (2-22) must be performed on ice.

2. Dice $2 \mathrm{~g} \mathrm{HCC}$ tissue into pieces of approximately $0.1 \mathrm{~mm}$ using a razor.

3. Resuspend the tissue particles in $10 \mathrm{~mL}$ ice-cold $\left(4{ }^{\circ} \mathrm{C}\right)$ homogenization buffer supplemented with $1 \times$ protease inhibitor cocktail.

4. Homogenize tissue particles in a Dounce homogenizer with at least 40 strokes.

5. Pass the homogenized suspension through a $100-\mathrm{mm}-$ diameter cell filter (pore size $125 \mu \mathrm{M}$ ) to remove debris.

6. Centrifuge the filtered solution at $1000 \times g$ for 10 $\min$ at $4{ }^{\circ} \mathrm{C}$, and collect the supernatant.

7. Resuspend the pellet from step $\mathbf{6}$ in $10 \mathrm{~mL}$ ice-cold $\left(4{ }^{\circ} \mathrm{C}\right)$ homogenization buffer supplemented with $1 \times$ protease inhibitor cocktail by vortexing.

8. Recentrifuged the samples at $1000 \times g$ for $10 \mathrm{~min}$ at $4{ }^{\circ} \mathrm{C}$, and collect the supernatant.

9. Resuspend the pellet from step $\mathbf{8}$ in $2 \mathrm{~mL}$ high-salt buffer with vortexing, and place the suspension on a rotary shaker for $30 \mathrm{~min}$ at $4{ }^{\circ} \mathrm{C}$ to extract nucleic proteins.

10. Centrifuge at $1000 \times g$ for $10 \mathrm{~min}$ at $4{ }^{\circ} \mathrm{C}$, and collect the supernatant.

11. Repeat steps 9-10, and collect the supernatant.

12. Combine the supernatants from steps $\mathbf{6 , 8 , 1 0}$, and 11, and go to step 23.

13. Harvest two dishes $(15 \mathrm{~cm})$ of confluent HEK293T cells by scraping, and wash the cells three times using $10 \mathrm{~mL}$ PBS with centrifugation at $1000 \times g$.

14. Resuspend the cells in $10 \mathrm{~mL}$ ice-cold $\left(4^{\circ} \mathrm{C}\right)$ homogenization buffer supplemented with $1 \times$ protease inhibitor cocktail.

15. Homogenize cells in a Dounce homogenizer with at least 40 strokes.

16. Centrifuge the homogenized mixture at $1000 \times \mathrm{g}$ for $10 \mathrm{~min}$ at $4^{\circ} \mathrm{C}$, and collect the supernatant.

17. Resuspend the pellet from step 14 by vortexing in $10 \mathrm{~mL}$ ice-cold $\left(4^{\circ} \mathrm{C}\right)$ homogenization buffer supplemented with protease inhibitor cocktail.

18. Centrifuge the samples at $1000 \times g$ for $10 \mathrm{~min}$ at $4{ }^{\circ} \mathrm{C}$, and collect the supernatant.

19. Repeat steps 15-16, and collect the supernatant.

20. Resuspend the pellet from step $\mathbf{1 7}$ in $2 \mathrm{~mL}$ highsalt buffer with vortexing to extract nuclear proteins, and place the suspension on a rotary shaker for $30 \mathrm{~min}$ at $4{ }^{\circ} \mathrm{C}$.

21. Centrifuge at $1000 \times g$ for $10 \mathrm{~min}$ at $4{ }^{\circ} \mathrm{C}$, and collect the supernatant.

22. Combine the supernatants from steps 14, 16, 17, and 19, and go to step 23.

23. Centrifuge the supernatant at $10,000 \times g$ for $30 \mathrm{~min}$. Separate the supernatant (which contains cytosolic and nuclear proteins; for further processing, go to step 26) and pellet (which contains mitochondria; for further processing, go to step 24) by carefully removing the supernatant using a pipette. Keep both fractions for further treatments.

24. Resuspend the pellet from step 23 in $1 \mathrm{~mL}$ mitochondria lysis buffer supplemented with protease inhibitor cocktail, and rotate gently at $4{ }^{\circ} \mathrm{C}$ for $30 \mathrm{~min}$ on a rotary shaker.

25. Centrifuge at $12,000 \times g$ for $15 \mathrm{~min}$ at $4{ }^{\circ} \mathrm{C}$, collect the supernatant (which contains mitochondrial proteins), and discard the pellet.

\section{Removal of Non-covalently Bonded Small Molecules from the Denatured Human Proteome • TIMING 2-3 H}

26. Add DTT (final concentration: $1 \mathrm{mM}$ ) to the cytosolic (from step 23) and mitochondrial (from step 25) proteomes to break disulfide bonds within proteins. Allow the reaction to proceed for $10 \mathrm{~min}$ on ice.

27. Add prechilled $\left(-80^{\circ} \mathrm{C}\right)$ acetone to the proteome to reach a final concentration of $85 \%(\mathrm{v} / \mathrm{v})$ to precipitate proteins. Place the sample at $-80^{\circ} \mathrm{C}$ for $30 \mathrm{~min}$ to allow complete precipitation of proteins.

! CAUTION Acetone is highly flammable and toxic; handle with caution.

28. Gently centrifuge at $800 \times g$ at $4{ }^{\circ} \mathrm{C}$ for $5 \mathrm{~min}$.

ACRITICAL Do not exceed $800 \times g$ during centrifugation to avoid tight packing of the protein pellet, which can cause inefficient washing in the following steps.

\section{? TROUBLESHOOTING}

29. Resuspend the pellets in $5 \mathrm{~mL}$ of $85 \%(\mathrm{v} / \mathrm{v})$ acetone on a vortex mixer for $2 \mathrm{~min}$. 
30. Centrifuge at $800 \times g$ at $4{ }^{\circ} \mathrm{C}$ for $5 \mathrm{~min}$, collect the pellet, and discard the supernatant.

31. Repeat steps 29-30 five to 10 times.

32. Vacuum- or air-dry the protein pellet.

-PAUSE POINT The dried pellet can be stored at $-80{ }^{\circ} \mathrm{C}$ until further processing.

\section{Release Amide-Bonded Modifiers from the Denatured Proteome with CobB. •TIMING: 4-5 H}

33. Dissolve $0.5-2 \mathrm{mg}$ protein from step 32 in $1 \mathrm{~mL}$ deionized water, and sonicate for $5 \mathrm{~min}$ at room temperature to increase solubility.

\section{?TROUBLESHOOTING}

34. Determine the protein concentration of the suspension using Bradford reagent.

35. Adjust the protein concentration of the suspension to $0.2 \mathrm{mg} / \mathrm{mL}$.

36. To $1 \mathrm{~mL}$ proteome suspension, add recombinant CobB (purity > 98\%; for reaction system, see Table 3; for preparation, see Table 4) to reach a proteome:CobB ratio of 100:1.

37. Allow the reaction to proceed at $37^{\circ} \mathrm{C}$ for $4 \mathrm{~h}$, and stop the reaction by adding 4 volumes of stop solution supplemented with $100 \mu \mathrm{M}$ adonitol, which serves as an internal control for metabolite quantification in subsequent processes.

38. Store the stopped reaction at $-80^{\circ} \mathrm{C}$ for more than $12 \mathrm{~h}$ to allow complete precipitation of all proteins in the reaction mix.

39. Centrifuge at $12,000 \times g$ for $10 \mathrm{~min}$ at $4{ }^{\circ} \mathrm{C}$, collect the supernatant, and discard the pellet.

40. Vacuum dry the supernatant (which contains CobBcleaved 2'-O-metabolite-ADP-ribose derivatives) in an Eppendorf vacuum drier at room temperature.

Table 3 Reaction system for demodification by CobB TIMING: $0.5 \mathrm{~h}$

The demodification reactions were carried out in a $600 \mu \mathrm{l}$ reaction mix contains:

\begin{tabular}{ll}
\hline Reagent name & Amount \\
\hline pH 7.5 HEPES buffer $(500 \mathrm{mM})$ & $60 \mu \mathrm{l}$ \\
DTT $(100 \mathrm{mM})$ & $6 \mu \mathrm{l}$ \\
$\mathrm{MgCl}_{2}(600 \mathrm{mM})$ & $6 \mu \mathrm{l}$ \\
$\mathrm{NAD}^{+}(100 \mathrm{mM})$ & $6 \mu \mathrm{l}$ \\
Substrate proteome $(10 \mu \mathrm{g} / \mathrm{ml})$ & $300 \mu \mathrm{l}$ \\
CobB $(5 \mathrm{mg} / \mathrm{ml})$ & $50 \mu \mathrm{l}$ \\
PMSF $(100 \mathrm{mM})$ & $0.3 \mu \mathrm{l}$ \\
$\mathrm{ddH}_{2} \mathrm{O}$ & Up to $600 \mu \mathrm{l}$ \\
\hline
\end{tabular}

Table 4 Preparation of recombinant CobB TIMING: 2 days

1. Clone the Salmonella enterica deacetylase CobB gene

(Supplementary Information 1 and 2) into the plasmid pET22b(+)-His.

2. Introduce the constructed expression plasmid into E. coli BL21

(DE3) cells with standard $\mathrm{CaCl}_{2}$ transformation.

3. Grown the transformed cells at $37^{\circ} \mathrm{C}$ in LB medium containing $50 \mu \mathrm{g} / \mathrm{mL}$ ampicillin.

4. Add IPTG to a final concentration of $1.0 \mathrm{mM}$ when the optical density at $600 \mathrm{~nm}$ of the culture reaches $0.6-0.8$.

5. Keep the IPTG-induced cells growing for $6 \mathrm{~h}$. Then, harvest the cells by centrifugation at $800 \times g$ for 5 min.

-PAUSE POINT The harvested cells can be stored at $-20^{\circ} \mathrm{C}$ for weeks before further processing.

6. Disrupt the cells using an ultra-high pressure continuous flow cell disrupter in ice-cold 1X PBS containing $1 \mathrm{mM} \mathrm{PMSF}$ and $0.5 \mathrm{mM}$ DTT.

! CAUTION PMSF is highly toxic; handle with caution.

7. Remove cell debris by centrifugation at $21,000 \times \mathrm{g}$ for $40 \mathrm{~min}$ at $4{ }^{\circ} \mathrm{C}$.

8. Load the supernatant $(10 \mathrm{~mL})$ onto a Nickel resin column, and process the column with the AKTA TM FPLC ${ }^{\text {TM }}$ System.

9. Wash the bound protein with 10 volumes of binding buffer, and elute the proteins using elution buffer.

10. Desalt the proteins using gel chromatography with desalination buffer.

11. Check the purity of the proteins using SDS-PAGE before storing at $-80^{\circ} \mathrm{C}$.

Table 5 LC/MS settings

1. HPLC elution solvents

The anionic ion-pair reagent HFBA was added to the mobile phase to improve analyte interactions with the stationary phase. An aqueous solution of HFBA (approximately 0.5 M) was diluted in water (mobile phase A) and methanol (mobile phase B) to a final concentration of $0.5 \mathrm{mM}$.

2. Gradient system (pair of two alternating columns)

The gradient system used two identical columns (Agilent Zorbax SB-C 18; $2.1 \mathrm{~mm} \times 50 \mathrm{~mm}, 1.8 \mu \mathrm{m}$; Waldbronn, Germany) connected to a 10-port two-position switching valve. Using the column switching valve and a second binary pump, the two columns were applied alternately. When one column was used for the analytical gradient, the other column was cleaned and re-equilibrated. From the prepared samples, $5 \mu \mathrm{L}$ was injected into the HPLC system. The analytical gradient (pump 1; flow rate: $0.5 \mathrm{~mL} / \mathrm{min}$ ) increased linearly from $10 \%$ B to $50 \%$ B within 11 min. After isocratic elution for $0.5 \mathrm{~min}$, the gradient returned to starting conditions until $11.6 \mathrm{~min}$ and isocratic flow was performed for $10 \%$ B from 11.6 to $12.5 \mathrm{~min}$ at $0.5 \mathrm{~mL} / \mathrm{min}$. This short return of pump 1 to starting conditions was necessary for flushing the tubing from the pump to switching valve before the freshly equilibrated second column was switched in for the next injection. Parallel to the analytical gradient, the other column was cleaned and equilibrated by pump 2; within $1.0 \mathrm{~min}$, the gradient was increased from 10\% B to 95\% B. The isocratic flow of 95\% B was held for $4.5 \mathrm{~min}$. From 5.5 to $6.5 \mathrm{~min}$, initial conditions of the analytical gradient $(10 \%$ B) were achieved and retained at isocratic flow until $12.5 \mathrm{~min}$ for flushing and equilibrating the column. Total time from injection to injection was $13.3 \mathrm{~min}$ (including the autosampler operation time of $0.8 \mathrm{~min})$. 
$\triangle$ CRITICAL Make sure the samples have been dried completely. Glass tubes should be capped immediately to avoid absorption of moisture from the environment.

41. Carry out LC/MS (go to step 43) and/or GC/MS (go to step 46) for analysis for metabolites.

\section{LC/MS Analysis of Cleaved Metabolites •TIMING: 2-3 H per Sample}

42. Add $100 \mu \mathrm{L} \mathrm{HCl} \mathrm{(3} \mathrm{M} \mathrm{in} \mathrm{1-butanol),} \mathrm{and} \mathrm{incubate}$ for $15 \mathrm{~min}$ at $60^{\circ} \mathrm{C}$ to release metabolites from the $2^{\prime}$-O-metabolite-ADP-ribose derivatives and form butyl esters.

43. Completely dry the samples under nitrogen, and refill with $100 \mu \mathrm{L}$ injection solvent (80\% water, $20 \%$ methanol, $0.1 \%$ formic acid).

44. Carry out LC/MS analysis directly using the prepared samples (for analysis settings, see Table 5).

\section{? TROUBLESHOOTING}

GC/MS Analysis of Cleaved Metabolites •TIMING: 4-5 H per Sample

$\triangle$ CRITICAL Samples subjected to GC/MS analysis need to be derivatized ( $\bullet$ TIMING $3 \mathbf{h}$ ) before analysis.

45. Add $50 \mu \mathrm{L}$ pyridine dissolved $250 \mathrm{mM}$ methoxyamine hydrochloride to the samples from step 40 to release metabolites from the 2 '-Ometabolite-ADP-ribose derivatives (for reaction details, see reference 13).

! CAUTION Methoxamine hydrochloride and pyridine are highly toxic; handle with caution. The derivation steps should be performed in a fume hood.

46. Incubate the reaction at $70{ }^{\circ} \mathrm{C}$ for $90 \mathrm{~min}$ with shaking.

47. To $50 \mu \mathrm{L}$ solution from step $\mathbf{4 1}$, add MTBSTFA solution (100 $\mu \mathrm{L}, 20 \%$ in pyridine).

! CAUTION MTBSTFA is highly toxic; handle with care.

48. Incubate the reaction at $30^{\circ} \mathrm{C}$ for $60 \mathrm{~min}$ with shaking.

$\triangle$ CRITICAL To avoid degradation by both MSTFA and the derivatized metabolites, strictly avoid moisture during manipulation.

49. Filter the derivatized products through a $0.22-\mu \mathrm{m}$ syringe-driven filter unit. The derivatized metabolites are in the pass-through solution.
Table 6 GC/MS settings

$\Delta$ CRITICAL Prior to GC-MS analysis, ensure that the instrument has been optimized. Details for our GC/MS workflow are listed below. Please be aware that other GC/MS methods with sufficient sensitivity, reproducibility, and linearity for the metabolites of interest can be used.

1. Connect an Agilent 5977B Mass Spectrometer to an Agilent 7890B gas chromatograph. Use 5977MS/Enhanced MassHunter software to control the GC/MS system.

GC settings:

Column: Agilent 19091S-433HP-5MS 5\% Phenyl Methyl Silox $325^{\circ} \mathrm{C}$ : $29.8 \mathrm{~m} \times 250 \mu \mathrm{m} \times 0.25 \mu \mathrm{m}$

Carrier gas: helium (> 99.999\% purity)

Carrier gas flow rate: $1 \mathrm{~mL} / \mathrm{min}$

Oven temperature program: $100^{\circ} \mathrm{C}$ for $3 \mathrm{~min}$, increase the temperature by $10^{\circ} \mathrm{C} / \mathrm{min}$ to $140^{\circ} \mathrm{C}$, increase the temperature by $8^{\circ} \mathrm{C} / \mathrm{min}$ to $260^{\circ} \mathrm{C}$, increase the temperature by $10^{\circ} \mathrm{C} / \mathrm{min}$ to $310^{\circ} \mathrm{C}$, and hold at this temperature for $5 \mathrm{~min}$.

Injection port temperature: $280^{\circ} \mathrm{C}$

Transfer line temperature: $250^{\circ} \mathrm{C}$

Injection volume: $1 \mu \mathrm{L}$

Mode: splitless

MS settings:

Ionization mode: electron ionization (El) mode

Electron energy: $70 \mathrm{eV}$

Ion source temperature: $250^{\circ} \mathrm{C}$

Scan frequency: $2.7 / \mathrm{s}$

Mass range: $50.00-600.00 \mathrm{~m} / \mathrm{z}$

2. Place the samples in the auto sampler tray for GC/MS analysis.

3. Create a sample list (or sequence list) that includes the metabolomic sample details.

4. Inject the pyridine standard at the beginning and the end of the sample analysis sequence.

50. Transfer $100 \mu \mathrm{L}$ derivatized metabolite solution into GC vials for GC/MS analysis (for settings, see Table 6).

$\triangle$ CRITICAL Analyze derivatized metabolites as soon as possible. The stability of derivatized metabolites at $80{ }^{\circ} \mathrm{C}$ can range from a few days to a few months.

\section{?TROUBLESHOOTING.}

\section{Data Analysis •TIMING: 1-3 H for each Sample}

51. Export the GC or LC peaks of each sample from step 43 or step 48 as a csv table.

52. Normalize peak areas in different tables to the internal control adonitol area.

53. Compare GC or LC peak areas of CobB-treated samples with those of matched untreated samples; 
those with 3-fold or higher increases represent possible positive hits.

\section{?TROUBLESHOOTING}

54. Obtain MS/MS spectra of possible positive hits and search against NIST mass spectral library to identify corresponding metabolites.

\section{Validation of Positive Hits • TIMING: 1-3 H for each Sample}

55. Synthesize a peptide containing the desired modification on $\varepsilon$ amine of lysine in the peptide.

56. Perform steps 26-51, check whether the positive identification of corresponding GC or LC peaks was increased by CobB, and produce MS/MS spectra with the synthetic modification.

57. Obtain authentic standard metabolites.

58. Generate GC or LC peaks and MS/MS spectra for the standard metabolite.

59. Compare the retention times and MS/MS spectra with those generated from experiment.

$\triangle$ CRITICAL Empirically, no more than a 0.5\% retention time shift in GC or LC is tolerated.

\section{Troubleshooting}

\begin{tabular}{|c|c|c|c|}
\hline Step & Problem & Possible reason & solution \\
\hline 28 & $\begin{array}{l}\text { Tight pellet } \\
\text { forming }\end{array}$ & $\begin{array}{l}\text { High centrifugation } \\
\text { speed or sticky } \\
\text { pellet }\end{array}$ & $\begin{array}{l}\text { Vortex to disperse } \\
\text { pellet before further } \\
\text { washing }\end{array}$ \\
\hline 33 & Mild turbidity & $\begin{array}{l}\text { Incomplete } \\
\text { dissolving of } \\
\text { denatured proteins }\end{array}$ & Centrifuge to remove \\
\hline 45 & $\begin{array}{l}\text { Unsteady ion } \\
\text { response }\end{array}$ & $\begin{array}{l}\text { Ion source } \\
\text { parameters not } \\
\text { optimized; unstable } \\
\text { liquid flow }\end{array}$ & $\begin{array}{l}\text { Optimize ion source } \\
\text { parameters; check } \\
\text { UPLC and connected } \\
\text { systems for leaks }\end{array}$ \\
\hline 45 & $\begin{array}{l}\text { High noise levels } \\
\text { (chemical/ } \\
\text { electronic) }\end{array}$ & $\begin{array}{l}\text { Detector damaged } \\
\text { and producing } \\
\text { discharges }\end{array}$ & $\begin{array}{l}\text { Arrange engineer } \\
\text { visit }\end{array}$ \\
\hline $\begin{array}{l}45 \\
50\end{array}$ & $\begin{array}{l}\text { Poor } \\
\text { chromatographic } \\
\text { peak shape }\end{array}$ & $\begin{array}{l}\text { Column degradation } \\
\text { or contamination }\end{array}$ & $\begin{array}{l}\text { Replace the GC/UPLC } \\
\text { column }\end{array}$ \\
\hline $\begin{array}{l}45 \\
50\end{array}$ & Carryover & $\begin{array}{l}\text { The sample is too } \\
\text { concentrated }\end{array}$ & $\begin{array}{l}\text { Optimize injection } \\
\text { volume and } \\
\text { concentrate } \\
\text { components in sample }\end{array}$ \\
\hline $\begin{array}{l}45 \\
50\end{array}$ & $\begin{array}{l}\text { High mass } \\
\text { spectrometer } \\
\text { pressure }\end{array}$ & $\begin{array}{l}\text { Gas infusion room } \\
\text { atmosphere }\end{array}$ & $\begin{array}{l}\text { Work through } \\
\text { connections on MS } \\
\text { for gas-tight seals; } \\
\text { arrange engineer visit }\end{array}$ \\
\hline 50 & $\begin{array}{l}\text { Unstable GC gas } \\
\text { flow or pressure }\end{array}$ & Leak in GC system & $\begin{array}{l}\text { Work through } \\
\text { connections on GC to }\end{array}$ \\
\hline
\end{tabular}

Methods (Continued)

\begin{tabular}{|c|c|c|c|}
\hline Step & Problem & Possible reason & solution \\
\hline & & & check for gas-tight seals \\
\hline 50 & Unsteady baseline & $\begin{array}{l}\text { Detector or } \\
\text { electronics fault }\end{array}$ & $\begin{array}{l}\text { Arrange engineer } \\
\text { visit }\end{array}$ \\
\hline 50 & $\begin{array}{l}\text { Absence or low } \\
\text { number of peaks in } \\
\text { all samples }\end{array}$ & $\begin{array}{l}\text { Incomplete vacuum } \\
\text { drying in step 40; } \\
\text { failed injection }\end{array}$ & $\begin{array}{l}\text { Ensure that the } \\
\text { samples have been } \\
\text { completely dried in } \\
\text { step 40; re-inject the } \\
\text { sample }\end{array}$ \\
\hline 53 & $\begin{array}{l}\text { Low number of } \\
\text { positive hits }\end{array}$ & $\begin{array}{l}\text { Low purity and } \\
\text { activity of CobB }\end{array}$ & $\begin{array}{l}\text { Preparation of } \\
\text { recombinant CobB } \\
\text { with high purity and } \\
\text { activity }\end{array}$ \\
\hline 53 & $\begin{array}{l}\text { High amino acid } \\
\text { intensity detected in } \\
\text { the untreated } \\
\text { samples (cell lysates } \\
\text { alone/CobB alone) }\end{array}$ & $\begin{array}{l}\text { Incomplete } \\
\text { removing of non- } \\
\text { covalently bonded } \\
\text { small molecules from } \\
\text { cell proteome/CobB }\end{array}$ & $\begin{array}{l}\text { Repeat steps 29-30 } \\
\text { more times; } \\
\text { preparation of } \\
\text { recombinant CobB } \\
\text { with high purity }\end{array}$ \\
\hline
\end{tabular}

\section{Abbreviations}

DTT: Dithiothreitol; EDTA: Ethylenediaminetetraacetic acid; GC/MS: Gas chromatography/mass spectrometry; IPTG: Isopropyl $\beta$-D-1-thiogalactopyranoside; LC/MS: Liquid chromatography/mass spectrometry; MTBSTFA: N-tertButyldimethylsilyl-N-methyltrifluoro-acetamide; PTM: Post-translational modification; SDS: Sodium dodecyl sulfate sodium salt

\section{Acknowledgements}

We thank Sheng-Hong Ma at the Institutes of Biomedical Sciences of Fudan University for his help with the analyses of GC-MS.

\section{Authors' Contributions}

S-M. Z. and X-D. H. conceived the concept. X-D. H., Q-J. W. W-J. Y. and Y. W. conducted the experiments. W. X., J-Y. Z. and P-C. L. supervised the experiments. S-M. Z. and X-D. H. wrote the manuscript. All authors read and discussed the manuscript.

\section{Funding}

This work was supported by Grants from the State Key Development Programs (973) of Basic Research of China (Nos. 2013CB911204, 2013CB531200, 2013CB945100, 2015AA020913), the Ministry of Science and Technology of China (2016YFA0500700), the National Natural Science Foundation of China (Nos. 31330023, 81722021, 81471454, 31671453, 81771627, 31521003, U1432242, 31425008), 863 programs of China (2015AA020913), and Science and Technology Municipal Commission of Shanghai, China (16JC1405300).

Availability of Data and Materials

Data of interest will be made available on request.

\section{Ethics Approval and Consent to Participate}

Human liver tissues were obtained from Shanghai Cancer Center, Fudan University with the sned consent from the patients and approval of the ethics committee of Fudan University.

\section{Consent for Publication}

Not applicable.

\section{Competing Interests}

The authors declare no competing financial interest.

\section{Author details}

${ }^{1}$ Institutes of Biomedical Sciences, Obstetrics \& Gynecology Hospital of Fudan University, State Key Lab of Genetic Engineering and School of Life Sciences, Shanghai, People's Republic of China. ${ }^{2} \mathrm{NHC}$ Key Lab of Reproduction Regulation (Shanghai Institute of Planned Parenthood Research), Fudan 
University, Shanghai 200032, People's Republic of China. ${ }^{3}$ Shanghai Institute of Immunology, Shanghai Jiao Tong University School of Medicine, Shanghai 200025, People's Republic of China. ${ }^{4}$ Key Laboratory for Tibet Plateau Phytochemistry of Qinghai Province, College of Pharmacy, Qinghai University for Nationalities, Xining 810007, People's Republic of China.

Received: 9 July 2019 Accepted: 9 October 2019

Published online: 01 December 2019

\section{References}

1. Feher Z, Szirak K. Signal transduction in fungi--the role of protein phosphorylation. Acta Microbiol Immunol Hung. 1999;46(2-3):269-71.

2. Graves JD, Krebs EG. Protein phosphorylation and signal transduction Pharmacol Ther. 1999;82(2-3):111-21.

3. McTigue JJ, Van Etten RL. An essential active-site histidine residue in human prostatic acid phosphatase. Ethoxyformylation by diethyl pyrocarbonate and phosphorylation by a substrate. Biochim Biophys Acta. 1978;523(2):407-21.

4. Potel $\mathrm{CM}$, et al. Widespread bacterial protein histidine phosphorylation revealed by mass spectrometry-based proteomics. Nat Methods. 2018;15(3): 187-90.

5. Chvapil M, Hurych J. Hydroxylation of proline in vitro. Nature. 1959; 184(Suppl 15):1145.

6. Martin TA, Corrigan JR, Waller CW. N-acylation of cysteine. J Org Chem. 1965;30:2839-40.

7. $\mathrm{Xu} \mathrm{H}$, et al. PLMD: an updated data resource of protein lysine modifications. J Genet Genomics. 2017:44(5):243-50.

8. Grunstein M. Histone acetylation in chromatin structure and transcription. Nature. 1997;389(6649):349-52.

9. Choudhary C, et al. Lysine acetylation targets protein complexes and Coregulates major cellular functions. Science. 2009;325(5942):834-40.

10. Wang $\mathrm{Q}$, et al. Acetylation of metabolic enzymes coordinates carbon source utilization and metabolic flux. Science. 2010;327(5968):1004-7.

11. Zhao $\mathrm{S}$, et al. Regulation of cellular metabolism by protein lysine acetylation. Science. 2010;327(5968):1000-4.

12. Martin C, Zhang Y. The diverse functions of histone lysine methylation. Nat Rev Mol Cell Biol. 2005;6(11):838-49.

13. Chen $Y$, et al. Lysine propionylation and butyrylation are novel posttranslational modifications in histones. Mol Cell Proteomics. 2007;6(5):812-9.

14. Colak $\mathrm{G}$, et al. Identification of lysine succinylation substrates and the succinylation regulatory enzyme CobB in E. coli. Mol Cell Proteomics. 2013.

15. Xie $Z$, et al. Lysine succinylation and lysine malonylation in histones. Mol Cell Proteomics. 2012;11(5):100-7.

16. Tan $M$, et al. Identification of 67 histone marks and histone lysine crotonylation as a new type of histone modification. Cell. 2011;146(6): 1016-28.

17. Guan $\mathrm{KL}$, et al. Generation of acetyllysine antibodies and affinity enrichment of acetylated peptides. Nat Protoc. 2010;5(9):1583-95

18. Carlson SM, et al. Proteome-wide enrichment of proteins modified by lysine methylation. Nat Protoc. 2014;9(1):37-50

19. He, X.D., et al., Sensing and Transmitting Intracellular Amino Acid Signals through Reversible Lysine Aminoacylations. Cell Metabolism, 2018. 27(1): p. 151-+

20. Phillips DM. The presence of acetyl groups of histones. Biochem J. 1963;87: 258-63.

21. Ambler RP, Rees MW. Epsilon-N-methyl-lysine in bacterial flagellar protein. Nature. 1959;184:56-7.

\section{Publisher's Note}

Springer Nature remains neutral with regard to jurisdictional claims in published maps and institutional affiliations.

Ready to submit your research? Choose BMC and benefit from:

- fast, convenient online submission

- thorough peer review by experienced researchers in your field

- rapid publication on acceptance

- support for research data, including large and complex data types

- gold Open Access which fosters wider collaboration and increased citations

- maximum visibility for your research: over $100 \mathrm{M}$ website views per year

At $\mathrm{BMC}$, research is always in progress.

Learn more biomedcentral.com/submissions 